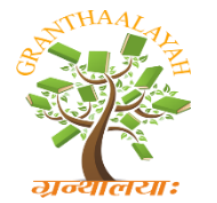

\author{
INTERNATIONAL JOURNAL OF RESEARCH - \\ GRANTHAALAYAH \\ A knowledge Repository
}

Management

\title{
PROBLEMS OF SALES FORCE: A STUDY WITH REFERENCE TO REAL ESTATE SECTOR
}

\author{
Venkateswarlu Karumuri ${ }^{* 1}$ \\ ${ }^{* 1}$ Assistant Professor, Department of Management Studies, Gayatri Vidya Parishad College for \\ Degree and PG courses, Visakhapatnam, Andhra Pradesh, India
}

\begin{abstract}
Real estate sector is one of the pre dominantly growing sectors in India as it is seen as both need fulfilment and as well as investment opportunity that gives stable returns over a period of time. Earlier the Indian real estate sector is in the hands of informal real estate agents and brokers. Now a days real estate sectors is growing in a more formal manner due to the government policies, rules and regulations. The government's allowance of FDI into real estate and announcement of regional balanced development increased the employment opportunities further. As this sector is highly influenced by so many players the real estate firms started focusing on increasing the goodwill to reach the customers. One of the goodwill ambassadors for the companies, are the sales force as they will be in continuous contact with the customer throughout the process. Sales force face many professional problems during the delivery of their work. A study has been conducted to understand the problems faced by real estate sales force in their jobs in the select cities of Andhra Pradesh. Anova study, mean and standard deviation techniques were used to project the results. The study identified significant problems faced by real estate sales force and offered suggestions to real estate firms in Andhra Pradesh.
\end{abstract}

Keywords: Real Estate; Sales Force; Professional Challenges; Problems.

Cite This Article: Venkateswarlu Karumuri. (2019). "PROBLEMS OF SALES FORCE: A STUDY WITH REFERENCE TO REAL ESTATE SECTOR." International Journal of Research - Granthaalayah, 7(1), 162-168. 10.29121/granthaalayah.v7.i1.2019.1044.

\section{Introduction}

Sales force play a significant role in acting as a significant interface between the business firms and customers. Salesforce represent the organisation to customers, interact with them, strengthen transactions, and serve as an instrument to scan and monitor the external environment (Sohi, 1996). Sales and marketing people show a key role for the success or failure of business as they are the actual brand ambassadors with their continuous interaction with customers. It is applicable to any industry and it is not an exception too, to real estate sector as this sector deals with different sections of people and their needs. The real estate sector in India is assuming greater and growing importance with the liberalisation of economy. Real Estate sector investments provide moderately 
steady aggregate returns that can be a variety combination of wage and capital development. It can be considered that Real Estate has a coupon-paying bond-like part in that it pays a standard, consistent salary stream, and it has a stock-like segment in that its esteem has an affinity to fluctuate. The ever fluctuating dynamics remains a challenge, given the demand for capital in this sector and the returns that real estate sector can potentially generate, the supply of capital keeps re-inventing itself. With real estate reaching a point of saturation in developed countries and the demand and prices falling, global real estate players are started looking at emerging economies such as India for tapping opportunities in real estate. Real estate sector covers residential housing, commercial offices, and retail outlets, trading spaces such as theatres, hotels and restaurants, industrial buildings such as factories and government buildings. It involves the purchase, sale, and development of land as well as residential and non-residential buildings. The activities of the real estate sector encompass the housing and construction sectors also. As this sector is fully dominated by huge number of players, the competition for customers is intensified all the time. The sales force have to continuously work hard to get the customers and convince them to sale. The sales force face often face difficulties in delivering their duties in a satisfied manner due to various reasons that affect their work productivity.

\section{Objectives of the Study}

The present study mainly focuses on professional problems or job related challenges faced by salesforce working in real estate sector and to offer suggestions to overcome the problems faced by real estate sector sales force to work effectively.

\section{Methodology of the Study}

The major objective of the study is to examine work related problems or professional problems in delivery of work of the sales force working in real estate sector firms of select cities of Andhra Pradesh, India. The study is mainly an empirical one. The primary data was collected from 450 sales force working in different real estate (housing and property development) firms in select cities of Andhra Pradesh i.e. Visakhapatnam, Vijayawada, Tirupati. The sales force were selected with convenience sampling and snowball sampling technique from the real estate firms. A structured questionnaire was specifically designed to get the responses in relation to objectives of the study. The questionnaire was framed in such a way that the respondents gave their opinions to the questions on a 5 point Likert scale. The sales force were asked to give their opinion (using a 5-point Likert scale, strongly agree [5], agree [4], agree to some extent [3], disagree [2], strongly disagree [1]) about the 12 variables. The secondary data was collected from data sources such as SAGE, EBSCO, ProQuest, Google scholar, etc.

\section{Results and Discussion}

An analysis of variance (ANOVA) was conducted to determine whether there were significant differences in Challenges of salesforce and socio economic profiles of sales force. Prior to the analysis, ANOVA assumptions were examined. The assumptions of univariate normality of residuals, homoscedasticity of residuals, and the lack of outliers were assessed. 
Paired $t$-tests were also calculated between each pair of measurements to further examine the differences among the variables. Tukey pairwise comparisons were conducted for all significant effects.

\subsection{ANOVA test for significant differences in Challenges of salesforce by Age}

The results of the ANOVA were significant at $F(4,445)=3.22, p=.013$, indicating there were significant differences in Challenges of salesforce among the levels of Age

Table 1.1: Analysis of Variance Table for Challenges of salesforce by Age

\begin{tabular}{|l|l|l|l|l|l|}
\hline Term & $\boldsymbol{S S}$ & $\boldsymbol{d} \boldsymbol{f}$ & $\boldsymbol{F}$ & $\boldsymbol{P}$ & $\boldsymbol{\eta}_{\mathbf{p}} \mathbf{2}$ \\
\hline Age & 5.48 & 4 & 3.22 & .013 & 0.03 \\
\hline Residuals & 189.37 & 445 & & & \\
\hline
\end{tabular}

Table 1.2: Mean, Standard Deviation, and Sample Size for Challenges of salesforce by Age

\begin{tabular}{|l|l|l|l|}
\hline Age & $\boldsymbol{M}$ & $\boldsymbol{S D}$ & $\boldsymbol{N}$ \\
\hline Below 25 & 2.51 & 0.68 & 65 \\
\hline Between 25-34 & 2.38 & 0.73 & 203 \\
\hline Between 35-44 & 2.58 & 0.47 & 119 \\
\hline Between 45-54 & 2.55 & 0.49 & 41 \\
\hline More than 55 & 2.78 & 0.84 & 22 \\
\hline
\end{tabular}

Note. - indicate sample size was too small to calculate statistic.

For the main effect of Age, the mean of Challenges of salesforce for between 25-34 $(M=2.38, S D$ $=0.73)$ was significantly smaller than for More than $55(M=2.78, S D=0.84), p=.048$. No other significant effects were found.

\subsection{ANOVA test for significant differences in Challenges of salesforce by Education Qualification}

The results of the ANOVA were significant, $F(4,445)=15.46, p<.001$, indicating there were significant differences in Challenges of salesforce among the levels of Education Qualification

Table 2.1: Analysis of Variance Table for Challenges of salesforce by Education Qualification

\begin{tabular}{|l|l|l|l|l|l|}
\hline Term & $\boldsymbol{S S}$ & $\boldsymbol{d} \boldsymbol{f}$ & $\boldsymbol{F}$ & $\boldsymbol{P}$ & $\boldsymbol{\eta}_{\mathbf{p}}$ \\
\hline Education Qualification & 23.78 & 4 & 15.46 & $<.001$ & 0.12 \\
\hline Residuals & 171.08 & 445 & & & \\
\hline
\end{tabular}

Table 2.2: Mean, Standard Deviation, and Sample Size for Challenges of salesforce by Education Qualification

\begin{tabular}{|l|l|l|l|}
\hline Educational qualification & $\boldsymbol{M}$ & $\boldsymbol{S D}$ & $\boldsymbol{N}$ \\
\hline Degree & 2.68 & 0.41 & 134 \\
\hline Doctorate & 2.82 & 0.77 & 30 \\
\hline
\end{tabular}




\begin{tabular}{|l|l|l|l|}
\hline Intermediate/Diploma & 2.71 & 0.50 & 53 \\
\hline Post Graduate & 2.24 & 0.71 & 198 \\
\hline X Class & 2.53 & 0.73 & 35 \\
\hline
\end{tabular}

For the main effect of Education Qualification, the mean of Challenges of salesforce for Degree $(M=2.68, S D=0.41)$ was significantly larger than for Post Graduate $(M=2.24, S D=0.71), p<$ .001. For the main effect of Education Qualification, the mean of Challenges of salesforce for Doctorate $(M=2.82, S D=0.77)$ was significantly larger than for Post Graduate $(M=2.24, S D=$ $0.71), p<.001$. For the main effect of Education Qualification, the mean of Challenges of salesforce for Intermediate/Diploma $(M=2.71, S D=0.50)$ was significantly larger than for Post Graduate $(M=2.24, S D=0.71), p<.001$. No other significant effects were found.

\subsection{ANOVA test for significant differences in Challenges of salesforce by Marital Status}

The results of the ANOVA were significant, $F(1,448)=14.30, p<.001$, indicating there were significant differences in Challenges of salesforce among the levels of Marital Status.

Table 3.1: Analysis of Variance Table for Challenges of salesforce by Marital Status

\begin{tabular}{|l|l|l|l|l|l|}
\hline Term & $\boldsymbol{S S}$ & $\boldsymbol{D} \boldsymbol{F}$ & $\boldsymbol{F}$ & $\boldsymbol{\eta}_{\mathbf{p}} \mathbf{2}$ \\
\hline Marital Status & 6.03 & 1 & 14.30 & $<.001$ & 0.03 \\
\hline Residuals & 188.82 & 448 & & & \\
\hline
\end{tabular}

Table 3.2: Mean, Standard Deviation, and Sample Size for Challenges of salesforce by Marital

\begin{tabular}{|l|l|l|l|}
\multicolumn{4}{|c}{ Status } \\
\hline Combination & $\boldsymbol{M}$ & $\boldsymbol{S D}$ & $\boldsymbol{N}$ \\
\hline Married & 2.59 & 0.56 & 241 \\
\hline Unmarried & 2.36 & 0.74 & 209 \\
\hline
\end{tabular}

For the main effect of Marital Status, the mean of Challenges of salesforce for Married $(M=2.59$, $S D=0.56)$ was significantly larger than for Unmarried $(M=2.36, S D=0.74), p<.001$.

\subsection{ANOVA test for the significant differences in Challenges of salesforce by Annual Salary}

The results of the ANOVA were significant, $F(3,446)=14.58, p<.001$, indicating there were significant differences in Challenges of salesforce among the levels of Annual Salary. The eta squared was 0.09 indicating Annual Salary explains approximately $9 \%$ of the variance in Challenges of salesforce.

Table 4.1: Analysis of Variance Table for Challenges of salesforce by Annual Salary

\begin{tabular}{|l|l|l|l|l|l|}
\hline Term & $\boldsymbol{S S}$ & $\boldsymbol{d} \boldsymbol{F}$ & $\boldsymbol{F}$ & $\boldsymbol{\eta}_{\mathbf{p}}^{2}$ \\
\hline Annual Salary & 17.41 & 3 & 14.58 & $<.001$ & 0.09 \\
\hline Residuals & 177.44 & 446 & & & \\
\hline
\end{tabular}


Table 4.2: Mean, Standard Deviation, and Sample Size for Challenges of salesforce by Annual Salary

\begin{tabular}{|l|l|l|l|}
\hline Salary & $\boldsymbol{M}$ & $\boldsymbol{S D}$ & $\boldsymbol{N}$ \\
\hline Between 1,00,000 and 2,00,000 & 2.63 & 0.44 & 130 \\
\hline Between 2,00,000 and 3,00,000 & 2.61 & 0.52 & 151 \\
\hline Less than 1,00,000 & 2.51 & 0.64 & 52 \\
\hline More than 3,00,000 & 2.16 & 0.88 & 117 \\
\hline
\end{tabular}

Note. - indicate sample size was too small to calculate statistic.

For the main effect of Annual Salary, the mean of Challenges of salesforce for Between 1,00,000 and 2,00,000 $(M=2.63, S D=0.44)$ was significantly larger than for More than 3,00,000 $(M=$ 2.16, $S D=0.88), p<.001$. For the main effect of Annual Salary, the mean of Challenges of salesforce for Between 2,00,000 and 3,00,000 $(M=2.61, S D=0.52)$ was significantly larger than for More than 3,00,000 $(M=2.16, S D=0.88), p<.001$. For the main effect of Annual Salary, the mean of Challenges of salesforce for Less than $1,00,000(M=2.51, S D=0.64)$ was significantly larger than for More than 3, 00,000 $(M=2.16, S D=0.88), p=.006$. No other significant effects were found.

\subsection{ANOVA test for the significant differences in Challenges of salesforce by Work Experience in the Current Organization}

The results of the ANOVA were significant, $F(4,445)=14.58, p<.001$, indicating there were significant differences in Challenges of salesforce among the levels of Work experience in the current organization. The eta squared was 0.12 indicating Work experience in the current organization explains approximately $12 \%$ of the variance in Challenges of salesforce.

Table 5.1: Analysis of Variance Table for Challenges of salesforce by Work experience in the current organization

\begin{tabular}{|l|l|l|l|l|l|}
\hline Term & $\boldsymbol{S S}$ & $\boldsymbol{d f}$ & $\boldsymbol{F}$ & $\boldsymbol{p}$ & $\boldsymbol{\eta}_{\mathbf{p}} \mathbf{2}$ \\
\hline Work experience in the current organization & 22.57 & 4 & 14.58 & $<.001$ & 0.12 \\
\hline Residuals & 172.28 & 445 & & & \\
\hline
\end{tabular}

Table 5.2: Mean, Standard Deviation, and Sample Size for Challenges of salesforce by Work experience in the current organization

\begin{tabular}{|l|l|l|l|}
\hline Combination & $\boldsymbol{M}$ & $\boldsymbol{S D}$ & $\boldsymbol{N}$ \\
\hline 1-3 years & 2.56 & 0.60 & 156 \\
\hline 3-5 years & 2.68 & 0.43 & 109 \\
\hline 5-7 years & 2.51 & 0.53 & 48 \\
\hline Less than 1 year & 2.09 & 0.80 & 102 \\
\hline More than 7 years & 2.69 & 0.72 & 35 \\
\hline
\end{tabular}

Note. - indicate sample size was too small to calculate statistic. 
For the main effect of Work experience in the current organization, the mean of Challenges of salesforce for 1-3 years $(M=2.56, S D=0.60)$ was significantly larger than for Less than 1 year $(M=2.09, S D=0.80), p<.001$. For the main effect of Work experience in the current organization, the mean of Challenges of salesforce for 3-5 years $(M=2.68, S D=0.43)$ was significantly larger than for Less than 1 year $(M=2.09, S D=0.80), p<.001$. For the main effect of Work experience in the current organization, the mean of Challenges of salesforce for 5-7 years $(M=2.51, S D=$ $0.53)$ was significantly larger than for Less than 1 year $(M=2.09, S D=0.80), p=.001$. For the main effect of Work experience in the current organization, the mean of Challenges of salesforce for Less than 1 year $(M=2.09, S D=0.80)$ was significantly smaller than for More than 7 years $(M=2.69, S D=0.72), p<.001$. No other significant effects were found.

\subsection{Problems of Salesforce}

Table 6: Problems of sales force in real estate sector

\begin{tabular}{|c|c|c|c|c|}
\hline & \multicolumn{4}{|c|}{ MeanSD SEM|Minimum Maximum } \\
\hline $\begin{array}{l}\text { Prospecting good leads is a major Problem for sales force in } \\
\text { real estate sector }\end{array}$ & 1.98 & 1.29 .06 & 1.00 & 4.00 \\
\hline Competing with the sales force of the competitor completely & 2.83 & 1.23 .06 & 1.00 & 4.00 \\
\hline coverage of entire sales area as planned by company & 2.57 & 1.16 .05 & 1.00 & 4.00 \\
\hline $\begin{array}{l}\text { Overcoming the sales objections raised by prospect } \\
\text { customers }\end{array}$ & 2.57 & 1.18 .06 & 1.00 & 4.00 \\
\hline $\begin{array}{l}\text { Too many competitors in the market making me not to get } \\
\text { prospect customers }\end{array}$ & $\mathrm{t} 2.37$ & 1.24 .06 & 1.00 & 4.00 \\
\hline $\begin{array}{l}\text { Customers are not fully believing organized real estate } \\
\text { players }\end{array}$ & 2.48 & 1.22 .06 & 1.00 & 4.00 \\
\hline The dominance of real estate brokers & 2.52 & 1.21 .06 & 1.00 & 4.00 \\
\hline Limited staff to reach the targets is a big Problem & 2.64 & 1.22 .06 & 1.00 & 4.00 \\
\hline Too much psychological stress at work is a big Problem & 2.46 & 1.20 .06 & 1.00 & 4.00 \\
\hline Too much of physical stress at work is a big Problem & 2.46 & 1.22 .06 & 1.00 & 4.00 \\
\hline $\begin{array}{l}\text { Mismatch between the customer expectations and features } \\
\text { of the available projects from real estate companies to meet } \\
\text { the customer needs }\end{array}$ & 2.45 & 1.25 .06 & 1.00 & 4.00 \\
\hline $\begin{array}{l}\text { My organization fails to provide me sufficient training } \\
\text { related to company and its products to meet the customer } \\
\text { requirements }\end{array}$ & 2.56 & 1.25 .06 & 1.00 & 4.00 \\
\hline $\begin{array}{l}\text { Government rules and regulations on real estate made the } \\
\text { job difficult }\end{array}$ & 2.45 & 1.24 .06 & 1.00 & 4.00 \\
\hline
\end{tabular}

The above table reveals that 'Competing with the sales force of the competitor completely' is the biggest Problem reported by the respondents in the study as having highest mean score of 2.83. The next significant Problem faced by salesforce is, 'limited staff to reach the targets' loaded with a mean score of 2.64.The others such as 'coverage of entire sales area as planned by company' (2.57), 'overcoming the sales objections raised by prospect customers' (2.57), 'organization's failure to provide sufficient training related to company and its products to meet the customer requirements' (2.56), and 'the dominance of real estate brokers' (2.52) are among the significant difficult Problems that the sales force are facing in real estate sector. 


\section{Managerial Implications}

Customer information requirement in real estate sector is influenced by both sentiments and needs. In this regard the sales person is expected to provide more information to clarify the doubt raised. In this regard the real estate firms should focus more on continuous training and development programmes to make them upto date with the market.

The real estate firms should support their sales force in identifying good prospects with the help of expert lectures. Due to the legal and statutory interventions of various acts related to real estate, the sales force faces the tough challenge in sales. So, the firms should encourage the sales force to explain the customers the role of legal and statutory interventions in real estate for transparent transactions between sellers and buyers.

As the real estate sector mostly influenced by unorganised real estate practices and real estate brokers, the real estate firms should focus on enhancement of brand image and goodwill through different practices so that the customers fully believe in organised real estate firms. The real estate firms are suggested to conduct sales force engagement activities and stress relieving programmes for sales force to reduce their stress levels.

\section{Conclusion}

The role of sales force is crucial for the success of the real estate firms. The real estate firms have to empower the sales force with required competencies and provide necessary support in delivering their duties efficiently. The support in the job front from management will definitely increase the morale of the sales force and leads work efficiency though the jobs are challenging and tough.

\section{References}

[1] Ashish Mittal and Kushboo Bhargava," AN OVERVIEW ON REAL ESTATE", 2011, pp. 27-28

[2] Bates, D., Mächler, M., Bolker, B., \& Walker, S. (2014). FITTING LINEAR MIXED-EFFECTS MODELS using lme4. arXiv preprint arXiv:1406.5823.

[3] Bharat Mittal, "AN EMPIRICAL STUDY OF THE TRENDS IN REAL ESTATE PRICES IN CHANDIGARH (INDIA)", A Dissertation presented in part consideration for the degree of" MA Management". 2007, 4, pp. 22-45

[4] Cohen, J. (1988). STATISTICAL POWER ANALYSIS FOR THE BEHAVIOUR SCIENCES (2ND ED.). St. Paul, MN: West Publishing Company.

[5] Mr. Debdoot Das.” REAL ESTATE (RESIDENTIAL) INDUSTRY: EVOLUTION OVER THE DECADES", IOSR Journal of Business and Management (IOSR-JBM), IESMCRC-2016 pp.4445.

[6] Sohi Ravipreet S. (1996). THE EFFECT OF ENVIRONMENTAL DYNAMISM AND HETEROGENEITY ON SALESPERSON'S ROLE PERCEPTIONS, PERFORMANCE AND JOB SATISFACTION. European Journal of Marketing, 30 (7), 49-67

[7] Retrieved from the source https://blog.sellingpower.com/gg/2009/10/10-tough-challengessalespeople-face-today-and-what-to-do-about-it-.html

*Corresponding author.

E-mail address: karumuri2007@ gmail.com 